\title{
THE MENTAL CAPACITY ACT 2005 (ENGLAND AND WALES) - A NEW LEGAL FRAMEWORK FOR DECISION-MAKING
}

\author{
Orla Ward, Office of Law Reform
}

\section{Introduction}

A major reform of the law on decision-making for people who lack mental capacity to make decisions for themselves has taken place recently in England and Wales with the passage of the Mental Capacity Act $2005^{1}$ ("the Act"). This reform is the product of over 15 years' research, analysis, consultation and scrutiny, beginning with a detailed Report by the Law Commission, undertaken between 1989 and $1995^{2}$ and including evidencebased scrutiny by a Parliamentary Joint Committee. ${ }^{3}$ Although some aspects attracted detailed debate, the Act enjoyed broad public and parliamentary support as a new legal framework on decision-making for people who lack capacity to make decisions for themselves.

Against a backdrop of complex and challenging socio-economic, demographic $^{4}$ and legal issues, the Act provides guidance for decisionmaking in relation to decisions involving property and affairs, medical treatment and welfare. It seeks to balance individual rights and autonomy with individual needs and protection. It is an amalgam of new provisions, revised provisions such as those previously found in the Enduring Powers of Attorney Act 1985 which dealt only with property and affairs, and a range of matters formerly found in the common law, most of which deal with medical treatment decisions. Many of the main elements of the Act will, therefore, resonate across other common law jurisdictions, including Northern Ireland.

The Act opens with a clear statement of principles, defines what it is to be incapable of making decisions, places the common law best interests doctrine on a statutory basis and creates five mechanisms for substitute or alternative decision-making:

- Acts in connection with care and treatment;

- Advance refusal of treatment which the person who has become incapable has decided previously;

1 The Mental Capacity Act 2005, together with Explanatory Notes can be found at: <http://www.dca.gov.uk/menincap/legis.htm>. The Act is not yet in force and will be supplemented by a detailed Code of Practice.

2 Report of the Law Commission for England and Wales, Mental Incapacity, Law Com 231 (March 1995): 〈http://www.lawcom.gov.uk>.

3 Report of the Joint Committee on the Draft Mental Incapacity Bill (as it was then titled) (Nov 2003): 〈http://www.publications.parliament.uk/pa/jt/jtdmi.htm>.

4 It is estimated that more than 2 million adults in England and Wales have limited capacity due to mental illness, brain injury or illnesses such as dementia. Significantly, given the ageing population, the prevalence of dementia increases with old age. 
- Power of attorney under which the person has delegated decision-making authority to another;

- Decisions by the new Court of Protection;

- Decisions made by a court-appointed deputy.

The Act brings clarity to the role of carers and professionals and introduces new legal, procedural and structural safeguards as well as a new criminal offence to ill-treat or neglect a person who lacks capacity. The following offers an overview of this important new legislation.

\section{Principles}

The Act opens with a statement of fundamental principles which must guide all substitute decisions made under the Act. The first principle of the Act is the presumption that a person has decision-making capacity unless it is proved otherwise. This reflects the importance of not 'labelling' people as necessarily incapable because they have a particular diagnosis. The second and fifth principles constitute a move towards an emphasis on maximising autonomy by providing that all practical steps must be taken to assist people to participate as fully as possible in decision-making and where intervention is required, this should be one that is the least restrictive of the person's rights and freedoms. The third principle requires that a person must not be treated as incapable merely because he or she makes an unwise decision. The fourth principle places the individuality of the person at the centre of the decision-making process and requires that any act done, or decision made, under the Act for or on behalf of a person who lacks capacity must be done, or made, in his best interests.

\section{People Who Lack Capacity - 'The Functional Approach'}

A person lacks capacity in relation to a matter if at the material time he or she is unable to make a decision in relation to the matter because of an impairment of, or a disturbance in the functioning of, the mind or brain. Assessment of capacity is, therefore, not a general assessment but is functional to the particular decision and the cognitive and other ability of a particular person, at a particular time. This part of the Act also includes a 'non-discrimination clause' which echoes the first principle, stating that lack of capacity cannot be established merely by reference to a person's age, appearance, condition, or an aspect of his behaviour, which might lead others to make unjustified assumptions about his capacity. Ultimately, if the issue of a person's capacity is disputed, the issue will be referred to the Court of Protection for a decision.

\section{Best Interests}

If a person lacks capacity, substitute decisions must be made in his or her best interests. This requirement reflects the common law position established in medical treatment cases such as $\operatorname{Re} F$ [1990] 2 AC 1 (HL) and $\operatorname{Re} M B$ [1997] 2 FLR 426, and applies to all of the various substitute decisionmaking mechanisms in the Act. The Act sets out a checklist of relevant factors which must be considered in deciding the person's best interests, including a duty to ascertain the person's past and present wishes, feelings, values and beliefs. There is also a duty, if it is practicable and appropriate, to 
consult anyone named by the person, the person's carers, any attorney appointed by the person, or any deputy appointed by the court. The test remains, however, an objective test of what would be in the person's best interests. It is not a substitution of what others think is right for the person. In relation to a decision that results in the refusal or withdrawal of lifesustaining treatment, the Act stipulates that the decision-maker must be not motivated by a desire to bring about death.

\section{Acts in Connection with Care and Treatment}

This part of the Act provides a statutory defence for people who make nonconsensual interventions in the form of giving everyday treatment, care and informal assistance to a person with incapacity. Without this statutory provision, such caring interventions as dressing a person, entering her home to clean it or driving her car to take her to a hospital appointment, might otherwise be potentially unlawful. This provision replaces the unclear and poorly understood common law doctrine of necessity and it is likely to be widely used and very important. The extent of intervention permissible includes restraint, provided that it necessary to prevent harm to the person with incapacity and proportionate to the likelihood of harm. It does not, however, permit restraint to such an extent as would constitute a deprivation of liberty contrary to article 5 on the European Convention on Human Rights.

\section{Lasting Power of Attorney}

A power of attorney enables a person ('donor'), when capable, to plan for future incapacity by making a provision for the delegation of decisionmaking authority to another person ('donee'). The Act replaces the system of enduring power of attorney, which permitted the delegation of decisionmaking authority in relation to his or her property and affairs only, with a new lasting power of attorney. One of the most significant features of the Act is the development of the role of the donee of a lasting power of attorney to include decisions relating to health and personal welfare, as well as property and affairs. This includes decisions to refuse consent to lifesustaining treatment, if this power has been expressly delegated to the donee by the donor. The new system has additional checks and balances. The donor can appoint different donees to make decisions in relation to different matters. Unlike the former system, there must be a certification of the donee's capacity to make a power of attorney and the power of attorney will only take effect after it has been registered with the new Office of the Public Guardian, which will investigate concerns about abuse.

\section{New System of Court Appointed Deputies}

A further mechanism for substitute decision-making is the power of the new Court of Protection to appoint a deputy or deputies to make decisions for the person with incapacity. The Court might appoint a person such as a social worker, a solicitor or a relative. As with the power of attorney, the scope of this decision-making authority can extend to health, personal welfare or property and affairs. After extensive debate in Parliament, however, it was decided that, unlike a donee of a lasting power of attorney, a deputy is not empowered to make decisions relating to the refusal or withdrawal of lifesustaining treatment. The Act also states that, in line with the principle of 
least intervention, a decision of the Court is to be preferred to the appointment of a deputy. If, however, an appointment of a deputy is made, it should be as limited as possible in scope and duration. The new Office of the Public Guardian will supervise the appointment and conduct of deputies and the new Court of Protection will have the power to require deputies to give security and to submit reports to the Public Guardian.

\section{Advance Refusal of Treatment}

The provisions relating to advance refusal of treatment represent the most contentious part of the statute. They attracted detailed debate in Parliament and in public, even though such refusals are, under the common law, legally binding (HE v A Hospital NHS Trust [2003] EWHC 1017]. It is often overlooked that such refusals apply not only to life-sustaining treatment but to all sorts of treatment. The Act brings improved clarity to this area of decision-making. In order to take effect, an advance refusal must be valid and applicable to the circumstances and the proposed treatment. Additional safeguards apply to the advance refusal of life-sustaining treatment. These advance refusals must state specifically that they apply to the treatment even if life is at risk and they must be written, witnessed and signed by the maker and the witness. Furthermore, in order to alleviate concerns about euthanasia, there is an express declaration that nothing in the Act is to be taken to affect the law relating to murder or manslaughter or assisting suicide.

\section{Independent Mental Capacity Advocate}

The Act provides that, where the national health service or the local authority is proposing serious medical treatment, or a move to hospital, care home or residential accommodation, for a person who lacks capacity and there is noone, other than a paid or professional carer, whom it would be appropriate to consult in determining the person's best interests, an independent mental capacity advocate must be instructed to represent the person. The advocate is a significant new safeguard and should help in determining and communicating what might be in the best interests of people with incapacity who are without friends or family and so are particularly vulnerable. Recourse to this provision will not be necessary where the person has nominated a person to be consulted in matters affecting his or her interests, or where a donee or a deputy has been appointed. The Act provides for Regulations to be made to extend the functions of the independent mental incapacity advocate to other circumstances.

\section{New Court of Protection}

The Act creates a new superior Court of record, the Court of Protection. The new Court replaces the previous Court of Protection, which was an office of the Supreme Court. The Court will have the same powers and privileges as the High Court. It will have powers to make declarations regarding capacity, to decide where a person with incapacity should live or with whom he or she should be in contact and to give or refuse consent to medical treatment. It will also have powers in relation to the control and management of a person's property and in relation to the performance of deputies and donees. The Court is an important new structure but, given the other informal and formal decision-making mechanisms, it is intended to be the forum of last resort, for the resolution of complex or sensitive cases. 


\section{Office of the Public Guardian}

The Public Guardian will be a new statutory official, appointed by the Lord Chancellor and with a duty to report to the Court, if so required. The Public Guardian will have an important supervisory role in relation to donees and deputies, for example, by maintaining a register of powers of attorney and deputies and investigating complaints. He or she will also work with other authorities and agencies when concerns are raised or there are allegations of abuse and will have power to access health and social security records.

\section{Northern Ireland}

The Mental Capacity Act 2005 does not extend to Northern Ireland. There is, however, some current statutory provision under the Enduring Powers of Attorney (Northern Ireland) Order 1987, which regulates the continuing action of donees in the event of the donor's incapacity and also under part 8 of the Mental Health (Northern Ireland) Order 1986, under which the High Court has jurisdiction over the management of the property and affairs of persons who are incapable by reason of mental disorder. In practice this jurisdiction is exercised primarily by the Office of Care and Protection. Much of the law on general decision-making capacity, however, is to be found in the common law. In order to begin to consider proposals which might be suitable for this jurisdiction, the Office of Law Reform ${ }^{5}$ is reviewing the framework provisions of the Mental Capacity Act 2005 and is engaging with a recently-established reference group of people with expertise in this area and with relevant sections of the Bamford Review ${ }^{6}$.

\section{Conclusion}

The Mental Capacity Act 2005 represents a significant legislative reform. It is the product of substantial research and consultation with stakeholder groups, such as people with incapacity, their carers and relatives and members of the caring, medical and legal professions. It is a sound framework for balancing autonomy and empowerment with safeguards and care. As it would be impossible for a statute to legislate for the many different circumstances that might arise, the Act is a framework statute, which will be heavily informed by a Code of Practice. As the statute progresses to implementation stage, it is planned to conduct a wide-ranging information and education programme, again working closely with stakeholders.

5 <http://www.olrni.gov.uk/>.

6 In October 2002 DHSSPS initiated a major, wide-ranging and independent review of the law, policy and provision affecting people with mental health needs or a learning disability in Northern Ireland. The Review Chair is Professor David Bamford and follows similar exercises in England and Scotland. 